of Oxford (Sub-committee on Adverse Reactions). The names of the other members of the Committee and its full terms of reference will be announced as soon as possible.

The report of the Joint Sub-committee proposed that the Health Ministers should appoint an independent expert Committee on Safety of Drugs which, with the assistance of three sub-committees, would advise, in the light of current medical and scientific knowledge, on the adequacy of toxicity tests of a now drug before it is submitted to clinical trial, and on the adequacy of clinical trials before it is released for general use, and would arrange for the collection of data about any adverse effects found afterwards.

\section{The Blood Group Reference Laboratory, London}

ON May 8, Lord Newton, the Joint Parliamentary Secretary, Ministry of Health, opened the new building of the Blood Group Reference Laboratory in the grounds of the Lister Institute, Chelsea Bridge Road, London, S.W.1. The Laboratory, which is administered by the Medical Research Council on behalf of the Ministry of Health and is directed by Dr. A. E. Mourant, issucs blood grouping sera for use by the National Blood Transfusion Service, by hospitals in the United Kingdom and by various laboratories overseas, and gives advice on clinical cases and technical problems referred to it by other laboratories; it is recognized by the World Health Organization as the Tnternational Blood Group Reference Laboratory. The Laboratory, because of its wide national and international connexions, has exceptional opportunities to examine rare types of blood and much research has been done on these. The Laboratory has also taken part in trials of the long-term preservation of blood by freezing ; a recent development is an investigation of antibodies against the white cells and platelets of blood which has an immediate application in transfusion cases and which is likely to be one of the important keys to the safe transplantation of organs such as kidneys. Built and equipped by the Ministry of Health, the Laboratory cost $£ 83,500$.

\section{The National Reference Library of Science and Invention}

IN answering a question regarding the availability of scientific and technological literature in London in the House of Commons on April 23, the Parliamentary Secretary for Science, Mr. D. Freeth, said that the Government considered that there was room for improvement in the provision of such literature in London and had already announced the establishment of the National Reference Library of Science and Invention on the South Bank, to be administered by the British Museum. This Library would incorporate the present Patent Office library and substantial holdings of current scientific material to be transferred from the British Museum. The acquisition of additional periodicals and books from all over the world to complement these two collections had already begun following the first annual grant to the British Museum of special funds for the purpose; building would be started early in 1964 .

\section{The International Council of Scientific Unions}

THE I.C.S.U. Review of World Science for January 1963, the first number of Vol. 5, is marked by two new features. First, an article by R. J. Forbes describing the Royal Netherlands Academy of Science and Letters inaugurates a series of articles on national academies and research councils. Secondly, an article, by O. Struve, on the International Astronomical Union, and two by $\mathrm{R}$. $\mathrm{H}$. Dicke on cosmology and relativity and by J. S. Hey on radio astronomy and cosmology, open a serios of survoys of the more lively disciplines falling within the ambit of the International Council of Scientific Unions. The present issue also includes an article by L. do Sitter on the relation between geology and geophysics and by $\mathrm{Dr}$. E. Wichers on the new scale of nuclidic masses and atomic weights.

\section{Journals on Geophysics}

THReE simultaneous developments in the literature of geophysics attest the recent extensive activity in this seience. First, the journal Geophysical Abstracts, hitherto issued quarterly as a bulletin of the United States Geological Survey, appears from January 1963 as a separate monthly publication of the United States Geological Survey, designed to provide abstracts of technical papers and books on the physics of the solid Earth, on the application of physical methods and techniques to geological problems, and on geophysical methods of exploration for mineral deposits, fuels and water. The monthly issues comprise about 360 abstracts each, in 90 pages. Geophysical Abstracts is available from the Superintendent of Documents, U.S. Government Printing Office, Washington 25, D.C., at a post-paid (foreign mailing) price of $5 \cdot 25$ dollars a year (twelve monthly issues and index). Secondly, the Journal of Geophysical Research, hitherto published monthly by the American Geophysical Union (1515 Massachusetts Avenue, N.W., Washington 5, D.C.), has become a semi-monthly from January 1963 and in size is expected to average about 6,000 pages annually (25 dollars a year). Thirdly, a new quarterly publication of the American Geophysical Union, entitled Reviews of Geophysics (8 dollars a year), has just appeared, and is intended to cover all fields of geophysics and specifically to provide overall views of particular areas of present-day interest. This is published with the aid of a grant from the National Science Foundation. A welcome feature of all these new developments, seldom encountered in these times, is that they have been brought about at a commendably low cost to the librarian.

\section{Particle Samplers}

Catalogut 930 (1963) issued by C. F. Casella and Co., Ltd., deals with particle samplers. Airborno particles, consisting of material so finely divided that thoy remain freely suspended in the air for long periods without settling, may be man-made from operations in mines or factories, or natural such as spores and pollen. Thoy may be of widely different form, size, chemical make-up, concentration, density, opacity, etc., so that no ono sampling instrument is suitable for all casos. In addition, the hazard may vary, as health in pneumoconiosis and epidemics, or safety in dust explosions, or quality in photographic film. The details given in the deseription of each type of sampler are such that the prospective user can make his appropriate choice. The 'thermal precipitator' is a short period sampler of dust particles up to $20 \mu$ diameter and has an aspiration rate of $7 \mathrm{ml} . / \mathrm{min}$. The 'long period dust sampler' is for particles less than $7 \mu$ in diamoter (the respirable range) and its aspiration rate is $2 \mathrm{ml} . / \mathrm{min}$.

The 'cascade impactor' samples liquid or solid particles of $0 \cdot 5-50 \mu$ diameter and the 'hexlet' large quantities of the respirable fraction of a dust eloud (less than $7 \mu$ in diameter) for subsequent analysis or weighing. Their respective aspiration rates are $17 \frac{1}{2}$ and $501 . / \mathrm{min}$. For toxic airborne contaminants such as plutonium dust there is the 'plutonium dust sampler' with an aspiration rate of $1,000 \mathrm{l} / \mathrm{min}$., and for radioactive particles in the breathing zone of its wearer the 'personal air sampler'. The 'airborne bacteria sampler' is suitable for sampling bacteria from a known volume of air for subsequent counting after incubation, and the 'Hirst spore trap' is a long-term sampler of airborne spores and pollens for their subsequent counting and identification. The evaluation of the sample under a mieroscope is the most tedious part of the dust sampling process, and the catalogue includes a description of a 'push-button counter' which is designed to assist and speed up the work. 